\title{
Changes of lake organic carbon sinks from closed basins since the Last Glacial Maximum and quantitative evaluation of human impacts
}

\author{
Yu Li ${ }^{1 *}$, Xinzhong Zhang ${ }^{1,2}$, Lingmei $\mathrm{Xu}^{1}$, Yuxin Zhang ${ }^{1}$, Wangting $\mathrm{Ye}^{1}$ and Yichan $\mathrm{Li}^{1,3}$
}

\begin{abstract}
Background: Closed basins occupy $21 \%$ of the world's land area and can substantially affect global carbon budgets. Conventional understanding suggests that the terminal areas of closed basins collect water and carbon from throughout the entire basin, and changes in lake organic carbon sinks are indicative of basin-wide organic carbon storages. However, this hypothesis lacks regional and global validation. Here, we first validate the depositional process of organic carbon in a typical closed-basin region of northwest China using organic geochemical proxies of both soil and lake sediments. Then we estimate the organic carbon sinks and human impacts in extant closed-basin lakes since the Last Glacial Maximum (LGM).

Results: Results show that $80.56 \mathrm{Pg}$ organic carbon is stored in extant closed-basin lakes mainly found in the northern mid-latitudes. Carbon accumulation rates vary from $17.54 \mathrm{~g} \mathrm{C} \mathrm{m}^{-2} \mathrm{yr}^{-1}$ during modern times, $6.36 \mathrm{~g} \mathrm{C} \mathrm{m}^{-2} \mathrm{yr}^{-1}$ during the mid-Holocene and $2.25 \mathrm{~g} \mathrm{C} \mathrm{m}^{-2} \mathrm{yr}^{-1}$ during the LGM. Then, we evaluated the influence by human activities during the late Holocene (in the past three thousand years). The ratio of human impacts on lake organic carbon storage in above closed basins is estimated to be $22.79 \%$, and human-induced soil organic carbon emissions in the past three thousand years amounted to $207 \mathrm{Pg}$.

Conclusions: While the magnitude of carbon storage is not comparable to those in peatland, vegetation and soil, lake organic carbon sinks from closed basins are significant to long-term terrestrial carbon budget and contain information of climate change and human impact from the whole basins. These observations improve our understanding of carbon sinks in closed basins at various time scales, and provide a basis for the future mitigation policies to global climate change.
\end{abstract}

Keywords: Carbon sinks, Closed basins, Human activities, Last Glacial Maximum, Climate change

*Correspondence: liyu@lzu.edu.cn

${ }^{1}$ Key Laboratory of Western China's Environmental Systems (Ministry of Education), College of Earth and Environmental Sciences, Center for Hydrologic Cycle and Water Resources in Arid Region, Lanzhou University, Lanzhou, China

Full list of author information is available at the end of the article

\section{Background}

Closed basins, defined as the regions where surface flow is unable to break topographic barriers and thus retains in a landlocked storage [32], occupy $30,873,561 \mathrm{~km}^{2}$ or about $21 \%$ of the world's land area [26, 53]. Largely due to far distances from oceans, most closed basins are located in drylands where aridity indexes are lower than 0.65 [19],Fig. 1a). Closed-basin carbon sinks have recently been recognized as significant components of original author(s) and the source, provide a link to the Creative Commons licence, and indicate if changes were made. The images or other third party material in this article are included in the article's Creative Commons licence, unless indicated otherwise in a credit line to the material. If material is not included in the article's Creative Commons licence and your intended use is not permitted by statutory regulation or exceeds the permitted use, you will need to obtain permission directly from the copyright holder. To view a copy of this licence, visit http://creativecommons.org/licenses/by/4.0/. The Creative Commons Public Domain Dedication waiver (http://creativeco mmons.org/publicdomain/zero/1.0/) applies to the data made available in this article, unless otherwise stated in a credit line to the data. 


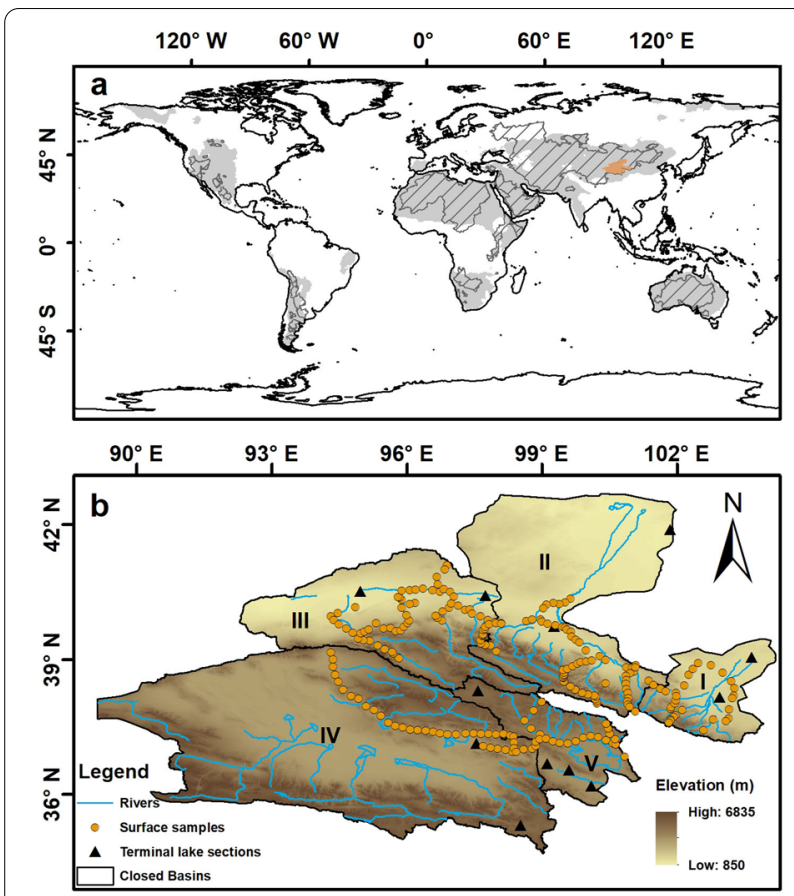

Fig. 1 Overview maps of study regions. a Global map of closed basins and locations of closed basins of the Qilian Mountains. The shaded parts show global drylands where aridity indexes are lower than 0.65 and the gray bars indicate global closed basins where there are no outflows to the oceans. $\mathbf{b}$ Detailed map of closed basins of the Qilian Mountains and locations of sampling sites. The Roman numerals represent various closed drainage basins, I: Shiyang River drainage basin, II: Heihe River drainage basin, III: Shule River drainage basin, IV: Qaidam drainage basin; V: Qinghai Lake drainage basin

the terrestrial carbon budgets and are believed to play important roles in the global carbon cycle [1, 25, 26, 53]. It has been estimated that closed basins currently bury at least $0.152 \mathrm{Pg}$ of dissolved inorganic carbon per year, which is comparable to the deep ocean carbon burial of $0.2 \mathrm{Pg} \mathrm{C} \mathrm{yr}^{-1}[26,40]$. Total dissolved inorganic carbon pool during the mid-Holocene was up to $739.1 \mathrm{Pg} \mathrm{C}$ in global closed basins, higher than contemporaneous carbon stock of global peatland (305 Pg C) $[26,50]$. However, controversies still exist in the mechanism and actual magnitude of organic carbon sink in closed basins.

As a unique geographic unit, closed basins usually have a relatively isolated and integrated carbon cycle $[25,26$, 58]. Since there is no outlet, terminal lake can be considered as the "ocean" for closed basin. The terminal lake concentrates sedimentary materials from throughout the whole basin, having the potential to sequester extensive terrestrial organic matter [26, 51]. This characteristic makes organic carbon storage in terminal lakes an advantageous indicator to imply carbon change of the whole basins. In addition, many studies have demonstrated that the recent variations in lacustrine deposits are closely related to anthropogenic factors $[3,16,21]$. Therefore, the terminal lake carbon sink can also be used to evaluate the human impacts in closed basins.

Closed basins of the Qilian Mountains, located in the arid region of northwest China, are appropriate areas to explore carbon storage mechanism (Fig. 1b). Here we evaluate changes of lake organic carbon sinks from closed basins of the Qilian Mountains as a case study for research into the mechanisms of closed-basin carbon sink. 234 soil samples were collected in total for analysis of organic proxies in order to validate the transformation of soil organic carbon in closed basins of the Qilian Mountains. The organic carbon content and ${ }^{14} \mathrm{C} /$ OSL (optically stimulated luminescence) dating results from twelve lake records in this region were used to estimate organic carbon changes since the LGM and human impacts during the late Holocene (Additional file 1: Table S1 and S2). Then we evaluated organic carbon sinks in extant closed-basin lakes at a larger spatial scale, based on the knowledge of carbon cycle in closed basins of the Qilian Mountains. The $\mathrm{pH}$, alkalinity and salinity derived from 82 closed-basin lakes were used to define weight coefficients for three different lake types (carbonate, sulfate and chlorine). Organic carbon accumulation rates since the LGM derived from 39 closed-basin lakes were reassigned according to the weight coefficients. Finally, we calculated the organic carbon storage in closed-basin lakes (mainly located in northern mid-latitudes) since the LGM and evaluated the human impacts both on organic carbon sinks and on soil organic carbon emissions.

\section{Results and discussion}

\section{Lake organic carbon storage in closed basins of the Qilian Mountains}

Accurate chronologies are of crucial importance in longterm carbon sequestration studies, however, ${ }^{14} \mathrm{C}$ ages in arid areas are often affected by the carbon reservoir which makes the measured age older than it should be $[29,36,43]$. There are two common approaches to solve this problem in lake sediments: dating different materials (such as terrestrial plant remains, shells, charcoals and bulk organic matters) by the same dating method and dating the same material by different dating methods (such as ${ }^{14} \mathrm{C}$, OSL, Electron Spin Resonance and U-series dating). In this study, ${ }^{14} \mathrm{C}$ ages were first corrected to remove any possible old-carbon effect according to age differences based on various dating materials or methods in original publications, then the corrected ${ }^{14} \mathrm{C}$ ages were calibrated to calendar years (Cal BP) using the Calib 7.1 program (Additional file 1: Table S1) [48]. Based on the dating results in closed basins of the Qilian Mountains, especially the consistence between OSL and calibrated ${ }^{14} \mathrm{C}$ ages in Zhuyeze Lake, we believe that the reservoir 
effect is relatively small in this region, which is acceptable for analyzing the millennial-scale carbon sink changes (Fig. 2b) [30].

Conventional understanding of closed basins suggests their terminal areas collect water and carbon from throughout their entire drainage basins [26, 53]. Here we validated this hypothesis in closed basins of the Qilian Mountains using organic geochemical proxies of both soils and lake sediments. Total Organic Carbon (TOC) contents from soil samples across closed basins of the Qilian Mountains show an overall increasing trend along with rising elevations, and this changing trend is

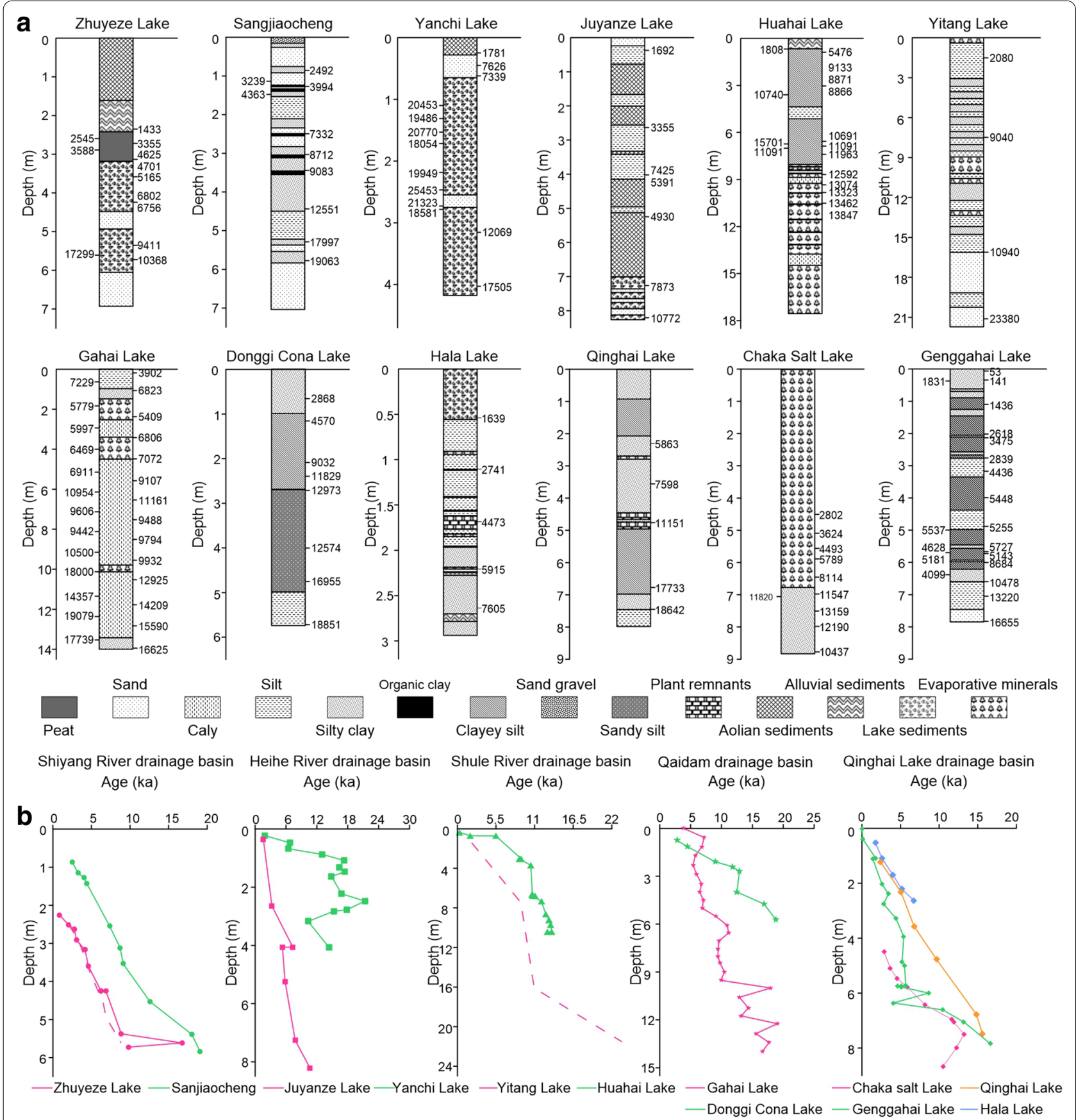

Fig. 2 The lithology and ${ }^{14} \mathrm{C} / \mathrm{OSL}$ dating results from 12 terminal lakes in the closed basins of the Qilian Mountains. a Lithology of the 12 lake sections. b Comparison of the calibrated ${ }^{14} \mathrm{C}$ (solid lines) and OSL ages (dashed lines) in the 5 closed basins of the Qilian Mountains. (Lithology data of Qinghai Lake are from Liu et al. [28], other lithology and ${ }^{14} \mathrm{C} / \mathrm{OSL}$ data sources see Additional file 1: Table S1) 
in accordance with those in the topsoil organic carbon content and modern net primary production (NPP) distributions which show that higher elevations have higher TOC and NPP (Fig. 3a, c, d). It is thus illustrated that the samples are representative and can effectively indicate the soil organic carbon changes of this region. Soil organic $\delta^{13} \mathrm{C}$ are generally scattered between $-26.96 \%$ to $-17.83 \%$ with an average value of $-23.41 \%$, indicating $\mathrm{C}_{3}$ plants with light $\delta^{13} \mathrm{C}$ values dominate the terrestrial plant types (Fig. 3a). This is consistent with the results from previous paleovegetation studies that concluded $\mathrm{C}_{4}$ plants have not developed in the arid area of northwest China since the LGM $[8,59]$. Therefore, the relatively light organic $\delta^{13} \mathrm{C}$ in lake records from closed basins of the Qilian Mountains is likely related to organic carbon inputs from terrestrial $\mathrm{C}_{3}$ plants rather than $\mathrm{C}_{4}$ plants.

The long-term variations of lithology and organic geochemical proxies in lake sediments follow a progressive depositional sequence (Fig. 2 and 3, Additional file 1: Fig. S2). During the LGM and following deglacial period, most lake records show relatively low TOC and various organic carbon sources. For example, fluvial facies and high organic $\delta^{13} \mathrm{C}$ in Sanjiaocheng section
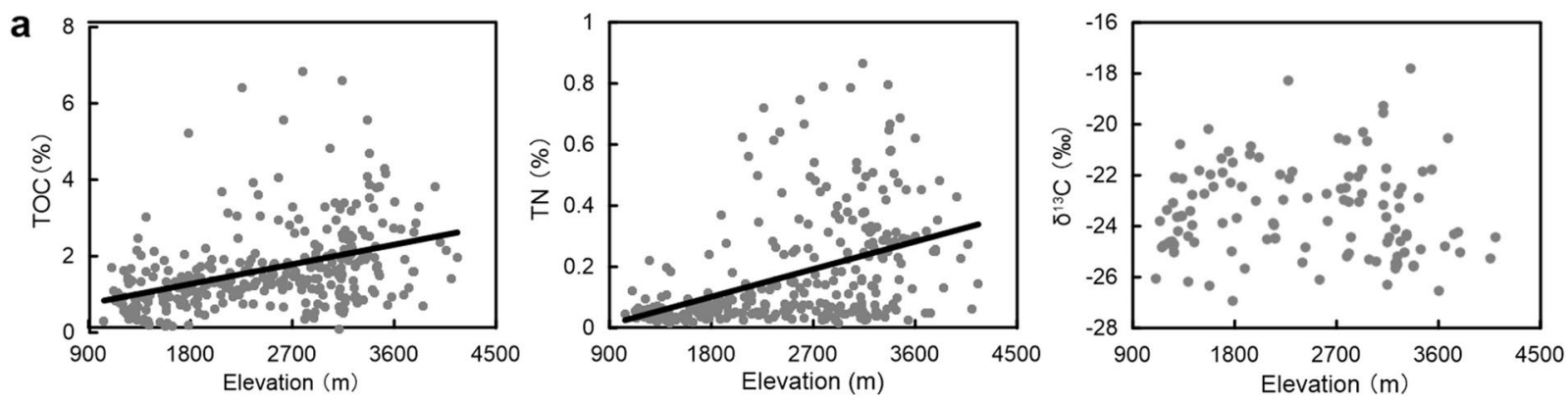

b Zhuyeze Lake Sanjiaocheng Juyanze Lake Yitang Lake Gahai Lake Donggi Cona Lake Hala Lake Qinghai Lake Chaka Salt Lake Genggahai Lake

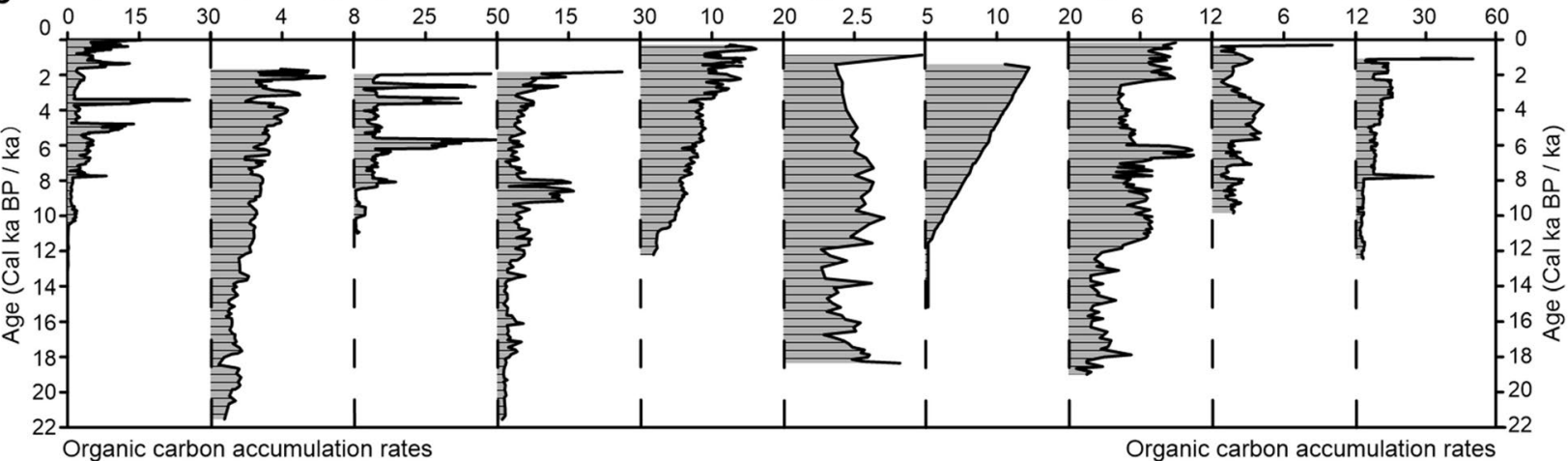

$\left(\mathrm{g} C \mathrm{~m}^{-2} \mathrm{yr}^{-1}\right)$

C

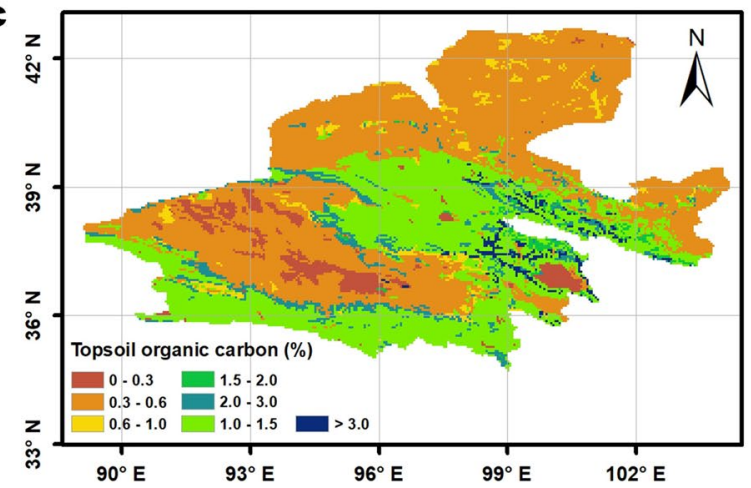

d

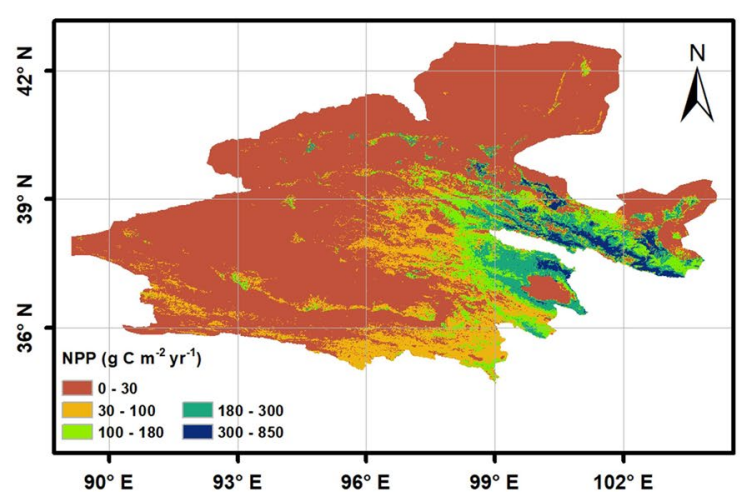

Fig. 3 Organic carbon related data from lake records and modern observations in closed basins of the Qilian Mountains. a TOC, TN, organic $\delta^{13} \mathrm{C}$ from soil samples versus elevations. b Organic carbon accumulation rates in closed-basin lakes of the Qilian Mountains. c Topsoil organic carbon contents (0-30 cm) [56]. d Modern NPP distributions (year 2000-2015) [45] 
indicate a large proportion of organic carbon input from terrestrial $\mathrm{C}_{3}$ plants, whereas autochthonous organic carbon dominate in Lakes Qinghai and Yitang indicated by low $\mathrm{C} / \mathrm{N}$ and $\delta^{13} \mathrm{C}[47,59,60]$. During the Holocene, the relatively high $\mathrm{C} / \mathrm{N}$ and TOC values in overlying lacustrine sections of most lakes suggest a stronger mixing effect of both terrestrial and aquatic sources of organic carbon, namely higher proportions of terrestrial organic carbon input than those during the LGM. Whatever the sources of organic carbon are, TOC is typically higher during the Holocene than during the LGM, implying similar responses of both terrestrial and aquatic ecosystems to long-term climate change. Changes of organic carbon sinks in the terminal lakes of closed basins can therefore indicate not only lake primary productivity but also terrestrial ecosystem productivity in their catchments.

Finally, the mean carbon accumulation rate in the 12 closed-basin lakes of the Qilian Mountains is estimated to $10.74 \mathrm{~g} \mathrm{C} \mathrm{m}^{-2} \mathrm{yr}^{-1}$ in modern times, $6.31 \mathrm{~g}$ $\mathrm{C} \mathrm{m}^{-2} \mathrm{yr}^{-1}$ in the mid-Holocene and $1.76 \mathrm{~g} \mathrm{C} \mathrm{m}^{-2} \mathrm{yr}^{-1}$ in the LGM (Additional file 1: Table S3). Using lake area calculated from HydroSHEDS products [24], lake organic carbon storage in closed basins of the Qilian Mountains since the LGM is up to $0.90 \mathrm{Pg}$ C. Comparatively, the modern soil organic carbon storage amounts to $3.32 \mathrm{Pg} \mathrm{C}$ based on Regridded Harmonized World Soil Database (HWSD) v1.2 [56].

\section{Organic carbon sinks and human impacts in extant closed-basin lakes}

Following the analysis of closed basins of the Qilian Mountains, we validate and evaluate the long-term organic carbon changes in other closed, mainly northern mid-latitude, basins with available organic geochemical proxies from their terminal lakes (Fig. 4, Additional file 1: Table S4, Figs. S4 and S5). During the LGM, Lakes Karakul, Luobupo and Zabuye in Asia, Lakes Bear and Red Rock in North America all show relatively low TOC, indicating similar change trends to those in closed basins of the Qilian Mountains (Additional file 1: Fig. S3) [12, $18,31,37,55]$. During the Holocene, comparatively high TOC and $\mathrm{C} / \mathrm{N}$ in most lake records imply higher productions in both terrestrial and aquatic ecosystems. According to the available chronologies from closed-basin lakes, most records show relatively weak carbon reservoir effect generally within 1000-2000 years which are not considered too significant for a millennial-scale research after using the carbon reservoir correction from original publications $[9,12,17,37]$. Therefore, the similar carbon sink mechanisms indicate that the experiences from closed basins of the Qilian Mountains can be used to assess organic carbon storages in other closed basins.

Uneven spatial distributions and research focuses in closed-basin lakes pose limits on available organic carbon data, especially in Africa and Australia. In order to more reasonably evaluate the carbon sinks at a larger spatial scale under a limited data condition, we firstly classified

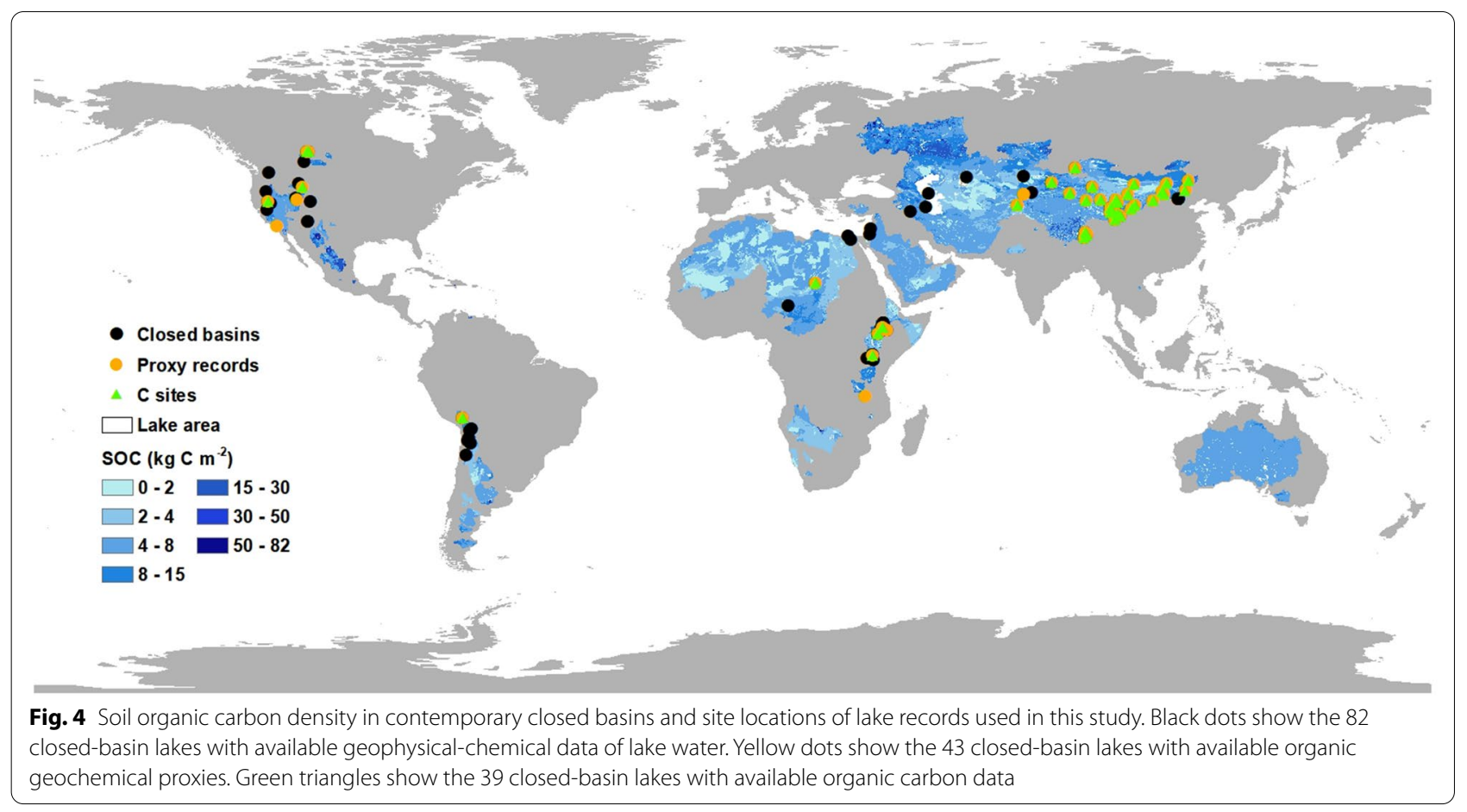


the extant closed-basin lakes into three types (carbonate, sulfate and chlorine), according to the geophysicalchemical characteristics of lake water (Additional file 1: Table S5) [26]. Terminal lake water characteristics can be considered as the comprehensive function of multiple regional factors and thus have great influence on organic carbon storage [46]. The weight coefficients were calculated as $0.021,0.221$ and 0.757 for carbonate, sulfate and chlorine lake types, respectively (see Methods for details). Then, the organic carbon accumulation rates since the LGM were multiplied by the weight coefficients according to their lake types. Results show modern mean organic carbon accumulation rate (CAR) is $17.54 \mathrm{~g} \mathrm{C} \mathrm{m}^{-2} \mathrm{yr}^{-1}, 6.36 \mathrm{~g} \mathrm{C} \mathrm{m}^{-2} \mathrm{yr}^{-1}$ in the midHolocene and $2.25 \mathrm{~g} \mathrm{C} \mathrm{m}^{-2} \mathrm{yr}^{-1}$ in the LGM (Additional file 1: Table S6). The total organic carbon sink in extant closed-basin lakes is $80.56 \mathrm{Pg} \mathrm{C}$ since the LGM. It is worth noting that the lake organic carbon storages calculated in this study is based on modern extant lake area (about 735,492.2 $\mathrm{km}^{2}$ [24]), and thus this estimate only represents the final residue of lake organic carbon sinks. However, the use of consistent lake area in the long-term calculation gives an advantage in quantitative evaluation of human impacts.

During the last few thousand years, human-induced land-use change directly affected the catchment landscape and regional hydrological response, and thus had strong influences on organic carbon storages both in soils and lakes [57]. Human-induced deforestation, pastoralism and agricultural cultivation destroy the stability of regional terrestrial ecosystems, resulting in accelerated soil erosion and lake sediment accumulation [10, 54]. According to recent authoritative studies regarding anthropogenic transformation of environments [3, 16], this paper proposes that intense human interference around the world begins three thousand years ago, and this point is indeed supported by higher CAR but relatively low TOC during the late Holocene in closed-basin lakes (Additional file 1: Table S7). This unusual phenomenon is closely related to terrestrial organic matter input due to human induced land-use change [54]. Therefore, we assumed the carbon accumulation from 22 to $3 \mathrm{ka}$ is not affected by human activities and completely represents natural variations, while the carbon accumulation during the last 3 ka suggests information on both natural and anthropogenic factors. According to curve fitting analysis of organic carbon accumulation rate from 22 to $3 \mathrm{ka}$, we obtained the potential natural CAR after 3 ka excluding human impacts. According to Eq. (8) in Methods, the ratio of human impacts is estimated to $22.79 \%$ on the organic carbon sinks in extant closedbasin lakes during the past three thousand years. However, the organic carbon sinks in terminal lakes contain only a portion of destroyed soil organic carbon, a majority of it being oxidized and released into the atmosphere. According to Eq. (9), we further estimate human-induced soil organic carbon emissions in the past three thousand years, amounting to $207 \mathrm{Pg} \mathrm{C}$.

\section{Role of closed-basin organic carbon sinks in global carbon budgets}

Regional process/mechanism studies help resolve the controversies regarding the organic carbon sink in closed basins and are key to achieving a comprehensive and credible global carbon budget [26]. By translating the results of our analysis of long-term carbon cycle mechanisms to other closed basins outside the Qilian Mountains, we provide a global perspective of organic carbon storage in closed-basin lakes. The organic carbon sink in terminal lakes indicates an overall increasing trend from LGM to present, in agreement with previous estimates of increases in northern peatland and global terrestrial carbon storage (Fig. 5) [22, 50]. Comparing the LGM to the Holocene, it seems that extant closed-basin lakes around the globe have lower organic carbon content and storage during glacial period than during interglacials. However, the timing of peak sedimentation and therefore organic carbon burial would have varied widely among different closed basins, due to regional differences in climate, vegetation and lake evolution since the LGM. Pluvial Great Basin during the LGM and Green Sahara during the Holocene are prime examples of this difference in lake evolution $[14,27,42,44]$. Another source of uncertainty in lake organic carbon sink estimation is that many closed-basin lakes, active since the LGM, have dried out in recent times, exposing organic carbon in lake sediments to oxidizing atmosphere conditions.

Based on the methods we used in this study, the total organic carbon pool in the extant closed-basin lakes from LGM to present is estimated to $80.56 \mathrm{Pg}$ C. It is relatively small in magnitude compared with other estimations of carbon sinks, such as inorganic carbon sink of closed basins (739.1 Pg C in the mid-Holocene) [26], peatland carbon burial (560 Pg C since the LGM) [50], organic carbon storage in the northern permafrost region (1672 Pg C) [49], vegetation carbon storage (405 Pg C in the LGM, $771 \mathrm{Pg} \mathrm{C}$ in pre-industrial Holocene) [41], soil carbon storage (520 Pg C in the LGM, $682 \mathrm{Pg} \mathrm{C}$ in pre-industrial Holocene) [41] and terrestrial carbon storage (3640 Pg C in the LGM) [11]. However, the organic carbon storage in the terminal areas of closed basins can be considered as an effective indicator of carbon change throughout the entire basin. On this basis, we further evaluate the human-induced soil organic carbon emissions in the past three thousand years amounting to $207 \mathrm{Pg}$. This 

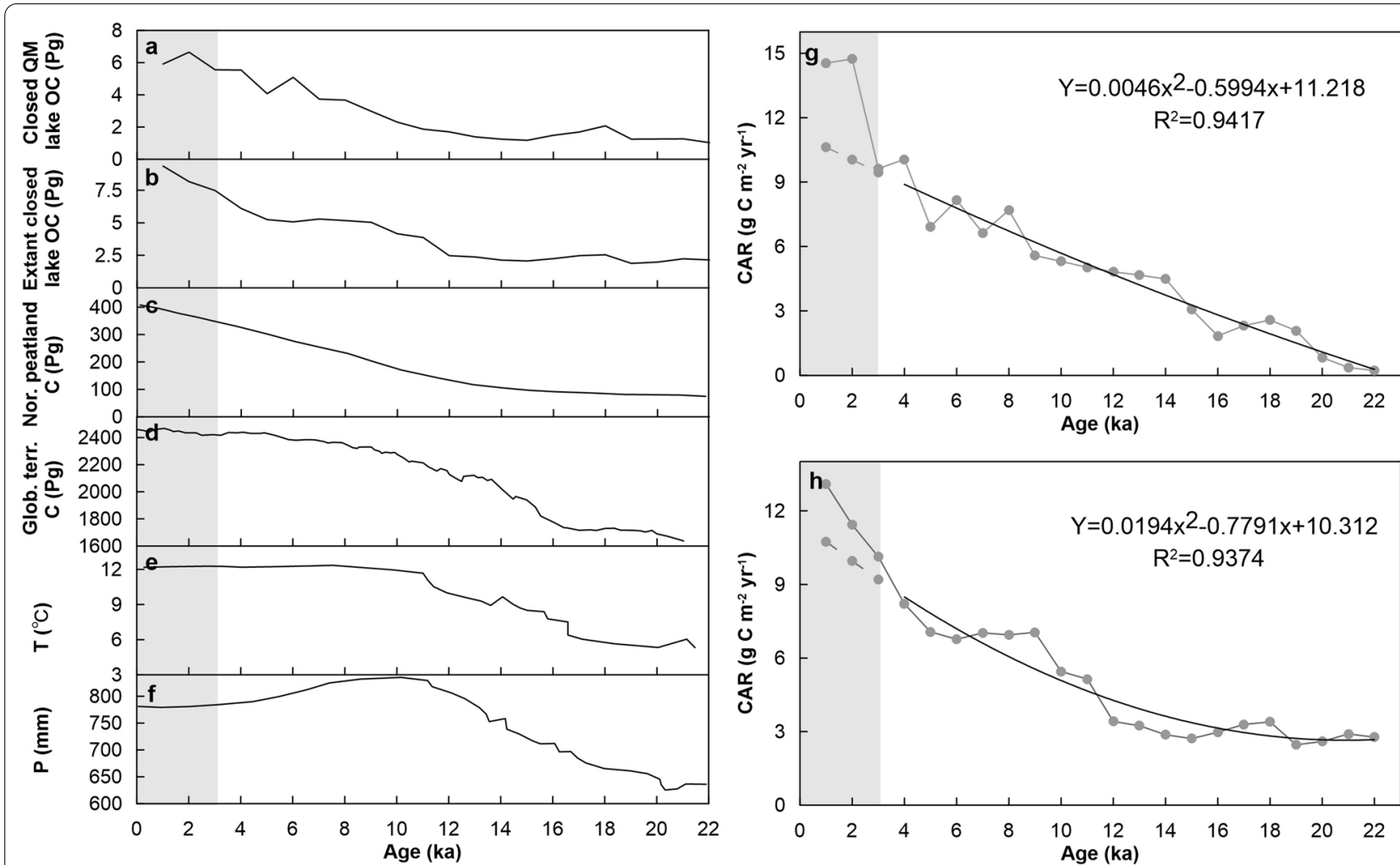

Fig. 5 Comparisons of organic carbon storage in extant closed-basin lakes with other terrestrial carbon storage and climate background since the LGM. a Organic carbon storage in closed-basin lakes of the Qilian Mountains and $\mathbf{b}$ in extant closed-basin lakes. $\mathbf{c}$ Northern peatland carbon stock [50]. d Global terrestrial carbon storage [22]. e Global land temperature change and $\mathbf{f}$ precipitation change [50]. $\mathbf{g}$ Temporal variation patterns of organic carbon accumulation rate at 1000-year bins in closed-basin lakes of the Qilian Mountains and $\mathbf{h}$ in extant closed-basin lakes. The gray shadow denotes the period including significant human impacts. The gray dashed line indicates processed CAR values when human impacts have been excluded

magnitude is larger compared to modern soil organic carbon storage (170.58 Pg).

Human activities have transformed and managed landscapes for thousands of years, altering global pattern of ecosystem functioning, carbon cycle, and climate [16]. Inland water carbon sinks and their influencing factors are key constituents associated with global ecosystem change, playing a potentially important role in global carbon budgets by balancing the carbon supplies from the atmosphere and associated watersheds and the net demand of primary producers [15]. Humans have deeply participated in above processes, and their impacts on both carbon storages and emissions will potentially change the global carbon cycle. Intergovernmental Panel on Climate Change (IPCC) has reported that humaninduced carbon emissions contribute significantly to global warming, with net $\mathrm{CO}_{2}$ emissions of $39.1 \pm 3.2$ $\mathrm{Pg} \mathrm{yr}^{-1}$ during 2007 to 2016 and global land surface air temperature increasing by $1.53^{\circ} \mathrm{C}$ since the pre-industrial period [20]. As research on carbon-climate feedbacks is crucial for both political and social decision-making globally, unremitting efforts are still required to quantitatively estimate human impacts to global carbon budget $[6,26]$.

\section{Conclusion}

This paper presents a regional study of organic carbon deposition in terminal lakes from the closed basins of the Qilian Mountains and a global study calculating and evaluating the lake organic carbon sinks in closed basins since the LGM. We find that the overall organic carbon sink in terminal lakes of closed basins is certainly not as significant as other carbon sinks, since its magnitude (80.56 Pg C from LGM to present) is much smaller than those in the peatland, vegetation and soil. However, it is still an important component of the terrestrial carbon budget, and the changes in lake organic carbon sinks are indicative of basin-wide organic carbon storages. On this basis, we further estimate that human-induced soil organic carbon emissions in the past three thousand years amount to $207 \mathrm{Pg}$. Our results contribute to the understanding on carbon sinks in closed basins at various 
time scales and provide bases for the future mitigation policies to global climate change.

\section{Methods \\ Data collection and analysis in closed basins of the Qilian Mountains}

Located at the transition area between drylands of northwest China, East Asian monsoonal region and QinghaiTibet Plateau, modern climate in the Qilian Mountains is strongly influenced by the combined effect of the Asian monsoons and westerly winds. Five closed basins cover this region, except for the Datong River drainage basin in the southeast part belonging to the Yellow River basin (Fig. 1b). Due to the wide range of altitude variation, the land use and land cover patterns show significant vertical zonality, with forest concentrated at high mountains and farmland distributed in lower basins (Additional file 1: Fig. S1). Since the Han Dynasty (2000 years ago), this region has been the core area of Silk Road connecting the central China to the west world, and thus affected extensively by human activities. Given the relatively isolated carbon cycle and long development history, closed basins of the Qilian Mountains are ideal for regional carbon sink and human impact researches.

In September 2018, we collected 234 surface soil samples in closed basins of the Qilian Mountains (Fig. 1b). The sampling sites (at least $5 \mathrm{~km}$ from each other) were taken as far away as possible from residential/industrial/ agricultural areas so as to be more indicative of natural vegetation and landscapes. Due to the low accessibility in many places of this mountainous area, soil sampling was done along main roads (though at least $50 \mathrm{~m}$ away from said roads), resulting in some limited coverage of sampling sites, especially in the south part of the Qilian Mountains. In addition, the southern Qaidam Basin and the northern Heihe Basin are far away from the core area of Qilian Mountains we focused on, so we didn't take soil samples from these areas. However, the sample ensembles are still fairly representative of overall organic geochemical characteristics of surface soils in closed basins of the region.

Lake sediment samples at Zhuyeze Lake in Shiyang River drainage basin were collected in October 2004 from a hand-excavated section near the edge of the lake at elevation of $1309 \mathrm{~m}$. The section was sampled at $2 \mathrm{~cm}$ intervals in the lake sediment layers and at $5 \mathrm{~cm}$ intervals otherwise, resulting in 292 samples for organic geochemical analyses. Six AMS ${ }^{14} \mathrm{C}$ dates and seven conventional ${ }^{14} \mathrm{C}$ dates were obtained from the shells and bulk organic matter, respectively. Also, totally 83 lake sediment samples at Yanchi Lake in Heihe River drainage basin were collected from a section at $5 \mathrm{~cm}$ intervals excavated in the middle part of the dried lake basin. Twelve AMS ${ }^{14} \mathrm{C}$ dates and two conventional
${ }^{14} \mathrm{C}$ dates were obtained from the pollen concentrates and bulk organic matter, respectively.

All above samples were measured for organic geochemical proxies of total organic carbon (TOC), carbon-nitrogen ratio $(\mathrm{C} / \mathrm{N})$ and stable carbon isotope $\left(\delta^{13} \mathrm{C}\right)$ in Analysis and Testing Center of Lanzhou University, and chronology of lake sediment samples were completed for conventional ${ }^{14} \mathrm{C}$ dating in Dating Laboratory of Lanzhou University and for Accelerator Mass Spectrometry (AMS) ${ }^{14} \mathrm{C}$ dating in Dating Laboratory of Peking University. Data from the other 10 lake records with measured organic geochemical proxies and reliable chronologies in closed basins of the Qilian Mountains were compiled from published resources (Fig. 1b, Additional file 1: Tables S1 and S2).

Organic geochemical proxies of TOC, $\mathrm{C} / \mathrm{N}$ and $\delta^{13} \mathrm{C}$ commonly used in paleoenvironmental studies were applied to validate the depositional process of organic carbon in closed basins of the Qilian Mountains. TOC can directly indicate the organic matter input, and further imply the regional primary productivity [5]. $\mathrm{C} / \mathrm{N}$ is considered an indicator of organic matter origin in lacustrine sediments [52]. C/N less than 10 indicates the organic matter mainly originates from aquatic plants, whereas $\mathrm{C} / \mathrm{N}$ between 14 and 23 means terrestrial organic matter input [33-35]. The organic $\delta^{13} \mathrm{C}$ can suggest the relative contribution of organic carbon from various terrestrial plants sources, with $-34 \%$ o to $-23 \%$ in $\mathrm{C}_{3}$ plants, $-22 \%$ to $-6 \%$ in $\mathrm{C}_{4}$ plants and $-20 \%$ o to $-10 \%$ in crassulacean acid metabolism (CAM) plants [39]. Likewise, the relative abundance of different aquatic plants during the sedimentary period can be inferred according to the ranges of $\delta^{13} \mathrm{C}$ value. Lake aquatic vegetation is dominated by submerged plant when it is $-12 \%$ o to $-20 \%$, emergent plant when it is $-24.00 \%$ o to $-30.00 \%$, and floating plant when it is about $-35.50 \%$ [7].

The CAR in closed basins of the Qilian Mountains since the LGM was calculated by the following equation $[2,38]$.

$$
C A R=S A R \times O C(\%) \times \rho \times(1-\phi)
$$

where SAR represents sediment accumulation rate based on age-depth data from individual lake records, OC is average organic carbon content during different periods, $\rho$ is sediment density calculated by Eq. (2) [38], and $\phi(\%)$ is porosity calculated by Eq. (3) [4].

$$
\begin{aligned}
& \rho=2.65-0.0523 \times \mathrm{OC}(\%) \\
& \varphi=\left(1-\frac{\mathrm{DBD}}{\rho}\right) \times 100 \%
\end{aligned}
$$

However, many lake records have no dry bulk density (DBD) data, thus for those without measured DBD values we use the following empirical relationships [4, 13]. 


$$
\begin{aligned}
& D B D=1.665 \times(O C)^{-0.887} \quad(\mathrm{OC}>6 \%) \\
& D B D=1.776-0.363 \times \ln (10 \times O C) \quad(\mathrm{OC} \leqq 6 \%)
\end{aligned}
$$

Finally, lake organic carbon storage (LOCS) was calculated as

$$
L O C S=A \times t \times C A R
$$

where $\mathrm{A}$ is lake area, $\mathrm{t}$ represents the duration of different time periods.

\section{Evaluations of organic carbon sink and human impact in extant closed basins}

In this study, we compiled 39 lake records containing reliable organic carbon content data in closed basins from published peer-reviewed literature (Fig. 4, Additional file 1: Table S4). These lakes are mostly located in the northern mid-latitudes. In order to reasonably estimate the organic carbon sinks in extant closed-basin lakes under a limited data condition, a reassignment of weight coefficients defined in this study is applied. Lake carbon sinks in closed basins are greatly affected by the geophysical-chemical conditions of lake water. Accordingly, data on lake area, $\mathrm{pH}$, alkalinity, salinity from 82 closed-basin lakes were assembled from published literatures (Additional file 1: Table S5). These lakes covering $63.35 \%$ of lake area in global closed basins, were further divided into three different types (carbonate, sulfate and chlorine) using information provided in the original publications. The discriminant analysis results indicate that $\mathrm{pH}$ values of the three different type of lakes have distinctive signatures and could be used to calculate organic carbon sinks under equilibrium conditions. As the lake area can directly influence the magnitude of lake organic carbon storage, we calculated the weight coefficient by $\mathrm{pH} \times$ lake area, to represent the proportion of organic carbon content in the three different lake types in extant closed-basin lakes.

The CAR in 39 closed-basin lakes with available TOC data was calculated using Eq. (1). Then CAR was multiplied by different weight coefficients according to their lake types classified above. Organic carbon storage in extant closed-basin lakes was calculated using Eq. (6), where $\mathrm{A}$ is total lake area, $\mathrm{t}$ represents deposition time span, and CAR is the mean carbon accumulation rate in extant closed-basin lakes. The modern soil organic carbon storage was calculated as

$$
S O C S=A \times S O C D
$$

where SOCD represents soil organic carbon density derived from the HWSD v1.2 [56], and A is area of closed basin excluding lake area.

We divided long-term variations of lake carbon accumulation into a part that completely represents natural variations and a human-influenced part that includes information on both natural and anthropogenic factors. According to curve fitting analysis of CAR in the natural part, we can obtain potential natural CAR in the human-influence part, namely excluding the human impacts. Then, the ratio of human impacts in last few thousand years (3000 years in this study) was defined as

$$
R_{H}=\left(C A R_{H}-C A R_{N}\right) / C A R_{N}
$$

where $\mathrm{CAR}_{\mathrm{H}}$ is the CAR containing influence from human activities, $\mathrm{CAR}_{\mathrm{N}}$ is the CAR excluding human impacts, namely under completely natural conditions.

Because change in lake organic carbon sink can be indicative of basin-wide organic carbon storages, we assumed that human activities result in soil organic carbon emission and lake organic carbon sink simultaneously and proportional coefficients between organic carbon storages in soil and lake are consistent throughout the past three thousand years. Therefore, the magnitude of the soil organic carbon emissions caused by human activities can be evaluated as

$$
S O C_{E}=L O C \times\left(S S R_{M} / L S R_{M}\right) \times R_{H}-L O C_{H}
$$

where LOC is the lake organic carbon sink over the past three thousand years, $\mathrm{SSR}_{\mathrm{M}}$ represents the sedimentary rate of modern soil organic carbon from data in Lal [23], $\mathrm{LSR}_{\mathrm{M}}$ represents the sedimentary rate of modern lake organic carbon from compiled lake records, $R_{H}$ is the ratio of human impact from Eq. (8), and $\mathrm{LOC}_{\mathrm{H}}$ is the human-induced organic carbon increase in the lake sediments calculated by $\mathrm{CAR}_{\mathrm{H}}$ minus $\mathrm{CAR}_{\mathrm{N}}$ in Eq. (8).

\section{Abbreviations}

AMS: Accelerator Mass Spectrometry; C/N: Carbon-Nitrogen Ratio; C: Carbon; CAM: Crassulacean acid metabolism; CAR: Carbon accumulation rate; CAR ${ }_{H}$ : Carbon accumulation rate containing human activities; $C_{A R}$ : Carbon accumulation rate under nature conditions; DBD: Dry bulk density; IPCC: Intergovernmental panel on climate change; LGM: Last glacial maximum; LOC: Lake organic carbon sink; LOC: Human-induce organic carbon storage of terminal lakes; LOCS: Lake organic carbon storage; LSR: Sedimentary rate of modern lake organic carbon; LSR: Modern lake organic sedimentary rates; NPP: Net primary production; OC: Organic carbon; OSL: Optically Stimulated Luminescence; Pg: Petagram (=1015 g); pH: Pondus hydrogenii; $R_{H}$ : Ratio of human impacts to organic carbon sinks; SAR: Sediment accumulation rate; SOCD: Soil organic carbon density; SOC: Soil organic carbon emissions caused by human activities; SSR: Sedimentary rate of modern soil organic carbon; $\mathrm{SSR}_{\mathrm{M}}$ : Modern soil organic sedimentary rates; $\mathrm{TN}$ : Total nitrogen; TOC: Total organic carbon. 


\section{Supplementary Information}

The online version contains supplementary material available at https://doi. org/10.1186/s13021-021-00191-6.

Additional file 1. Additional figures and tables.

\section{Acknowledgements}

The authors are very grateful to the editor Georgii Alexandrov and to two anonymous reviewers for their constructive comments and suggestions. We are also thankful to Spencer Staley (University of New Mexico, USA) for language editing.

\section{Authors' contributions}

YL conceived and designed the study. XZZ and LMX conducted the analyses and prepared the manuscript. All authors read and approved the final manuscript.

\section{Funding}

This work was supported by the National Key Research and Development Program of China (No. 2019YFC0507401); the National Natural Science Foundation of China (Grant Nos. 42077415, 41822708); the Second Tibetan Plateau Scientific Expedition and Research Program (STEP) (Grant No. 2019QZKK0202); the Strategic Priority Research Program of Chinese Academy of Sciences (Grant No. XDA20100102); the 111 Project (BP0618001).

\section{Availability of data and materials}

Boundaries of closed basins used in this study are available from the HydroBASINS product developed by the Conservation Science Program of World Wildlife Fund (WWF) at https://www.hydrosheds.org/page/hydrobasins. The NPP data are available from the Numerical Terradynamic Simulation Group of University of Montana at http://www.ntsg.umt.edu/project/modis/mod17. php. The HWSD v1.2 data are available from Oak Ridge National Laboratory Distributed Active Archive Center at http://dx.doi.org/10.3334/ORNLDAAC/ 1247. The land use and vegetation types data are available from Resource and Environment Data Cloud Platform at http://www.resdc.cn. Data from closed-basin lake records collected or compiled in this study are included in additional file.

\section{Declarations}

\section{Competing interests}

The authors declare that they have no competing interests.

\section{Author details}

${ }^{1}$ Key Laboratory of Western China's Environmental Systems (Ministry of Education), College of Earth and Environmental Sciences, Center for Hydrologic Cycle and Water Resources in Arid Region, Lanzhou University, Lanzhou, China. ${ }^{2}$ Department of Geosciences and Geography, University of Helsinki, Helsinki, Finland. ${ }^{3}$ Department of Geosciences, University of Arkansas, Fayetteville, USA.

Received: 20 October 2020 Accepted: 6 September 2021

Published online: 17 September 2021

\section{References}

1. Ahlström A, Raupach MR, Schurgers G, Smith B, Arneth A, Jung M, Reichstein R, Canadell JG, Friedlingstein P, Jain AK, Kato E, Poulter B, Sitch S, Stocker BD, Viovy N, Wang YP, Wiltshire A, Zaehle S, Zeng N. The dominant role of semi-arid ecosystems in the trend and variability of the land $\mathrm{CO}_{2}$ sink. Science. 2015;348(6237):895-9. https://doi.org/10.1126/science. aaa1668.

2. Alin SR, Johnson TC. Carbon cycling in large lakes of the world: A synthesis of production, burial, and lake atmosphere exchange estimate. Global Biogeoche Cy. 2007;21:1-12. https://doi.org/10.1029/2006GB002881.

3. ArchaeoGLOBE Project. Archaeological assessment reveals Earth's early transformation through land use. Science. 2019;365:897-902. https://doi. org/10.1126/science.aax1192.
4. Avnimelech Y, Ritvo G, Meijer LE, Kochba M. Water content, organic carbon and dry bulk density in flooded sediments. Aquacult Eng. 2001:25:25-33.

5. Balascio NL, D"Andrea, W.J., Bradley, R.S., Perren, B.B., . Biogeochemical evidence for hydrologic changes during the Holocene in a lake sediment record from southeast Greenland. Holocene. 2013;23:1428-39. https:// doi.org/10.1016/S0144-8609(01)00068-1.

6. Ballantyne AP, Andres R, Houghton R, Stocker B, Wanninkhof R, Anderegg W, Cooper L, DeGrandpre M, Tans P, Miller J, Alden C, White J. Audit of the global carbon budget: estimate errors and their impact on uptake uncertainty. Biogeosciences. 2015;12:2565-84. https://doi.org/10.5194/ bg-12-2565-2015.

7. Bowen R. Isotopes and climates. London: Elsevier Applied Science; 1991. p. 128-31.

8. Brincat D. Molecular isotopic stratigraphy of long-chain alkanes in Lake Baikal Holocene and glacial age sediments. Org Geochem. 2000;31:28794. https://doi.org/10.1016/S0146-6380(99)00164-3.

9. Chen CTA, Lan HC, Lou JY, Chen YC. The dry Holocene megathermal in Inner Mongolia. Palaeogeogr Palaeoecol. 2003;193:181-200. https://doi. org/10.1016/s0031-0182(03)00225-6.

10. Chen, E., Timmermann A., Baldi B., Moore A., Lyons R., Lee S., Kalsbeek A., Petersen D., Rautenbach H., Förtsch H., Bornman M., Hayes V., 2019. Human origins in a southern African palaeo-wetland and first migrations. Nature. https://www.nature.com/articles/s41586-019-1714-1.

11. Ciais P, Tagliabue A, Cuntz M, Bopp L, Scholze M, Hoffmann G, et al. Large inert carbon pool in the terrestrial biosphere during the Last Glacial Maximum. Nat Geosci. 2012;5(1):74-9. https://doi.org/10.1038/ngeo1324.

12. Dean W, Rosenbaum J, Skipp G, Colman S, Forester R, Liu A, Simmons K, Bischoff J. Unusual Holocene and late Pleistocene carbonate sedimentation in Bear lake, Utah and Idaho USA. Sediment Geol. 2006;185:93-112. https://doi.org/10.1016/j.sedgeo.2005.11.016.

13. Dean WE, Gorham E. Magnitude and significance of carbon burial in lakes, reservoirs, and peatlands. Geology. 1998;26:535-8. https://doi.org/ 10.1130/0091-7613(1998)026\%3c0535:masocb\%3e2.3.co;2.

14. Drake NA, Blench RM, Armitage SJ, Bristow CS, White KH. Ancient watercourses and biogeography of the Sahara explain the peopling of the desert. Proc Natl Acad Sci. 2011;108(2):458-62. https://doi.org/10.1073/ pnas.1012231108.

15. Gao Y, Jia J, Lu Y, Yang T, Lyu S, Shi K, Zhou F, Yu G. Determining dominating control mechanisms of inland water carbon cycling processes and associated gross primary productivity on regional and global scales. Earth Sci Rev. 2021;213: 103497. https://doi.org/10.1016/j.earscirev.2020. 103497.

16. Garcin Y, Deschamps P, Ménot G, Saulieu G, Schefuß E, Sebag D, Dupont L, Oslisly R, Brademann B, Mbusnum K, Onana J, Ako A, Epp L, Tjallingii R, Strecker M, Brauer A, Sachse D. Early anthropogenic impact on western central African rainforests 2,600 y ago. PNAS. 2018;115:3261-6. https:// doi.org/10.1073/pnas.1715336115.

17. Eggermont H, Verschuren D, Fagot M, Rumes B, Bocxlaer B. Aquatic community response in a groundwater-fed desert lake to Holocene desiccation of the Sahara. Quaternary Sci Rev. 2008;27:2411-25. https://doi.org/ 10.1016/j.quascirev.2008.08.028.

18. Heinecke L, Mischke S, Adler K, Barth A, Biskaborn B, Plessen B, Nitze I, Kuhn G, Rajabov I, Herzschuh U. Climatic and limnological changes at lake karakul Tajikistan. during the last 29 cal ka. J Paleolimnol. 2017;58:317-34. https://doi.org/10.1007/s10933-017-9980-0.

19. Huang J, Li Y, Fu C, Chen F, Fu Q, Dai A, Shinoda M, Ma Z, Guo W, Li Z, Zhang L, Liu Y, Yu H, He Y, Xie Y, Guan X, Ji M, Lin L, Wang S, Yan H, Wang $G$. Dryland climate change: recent progress and challenges. Rev Geophys. 2017;55(3):719-78. https://doi.org/10.1002/2016RG000550.

20. Intergovernmental Panel on Climate Change (IPCC), 2019. IPCC Special Report on Climate Change, Desertification, Land Degradation, Sustainable Land Management, Food Security, and Greenhouse gas fluxes in Terrestrial Ecosystems. https://www.ipcc.ch/srccl/.

21. Kaplan JO. Holocene carbon cycle: Climate or humans? Nat Geosci. 2015;8:335-6. https://doi.org/10.1038/ngeo2432.

22. Kaplan J, Prentice IC, Harrison SP, Bartlein PJ. Global vegetation and terrestrial carbon cycle changes after the last ice age. New Phytol. 2011;189:988-98. https://doi.org/10.1111/j.1469-8137.2010.03620.x.

23. Lal R. Carbon sequestration in dryland ecosystems. Environ Manage. 2004;33:528-44. https://doi.org/10.1007/s00267-003-9110-9. 
24. Lehner B, Grill G. Global river hydrography and network routing: baseline data and new approaches to study the world's large river systems. Hydrol Process. 2013;27:2171-86. https://doi.org/10.1002/hyp.9740.

25. Li Y, Wang Y, Houghton RA, Tang LS. Hidden carbon sink beneath desert. Geophys Res Lett. 2015;42:5880-7. https://doi.org/10.1002/2015GL0642 22.

26. Li Y, Zhang C, Wang N, Han Q, Zhang X, Liu Y, Xu L, Ye W. Substantial inorganic carbon sink in closed drainage basins globally. Nat Geosci. 2017:10:501-6. https://doi.org/10.1038/ngeo2972.

27. Liefert DT, Shuman BN. Pervasive desiccation of North American lakes during the Late Quaternary. Geophys Res Lett. 2020;47(3):e2019GL086412. https://doi.org/10.1029/2019GL086412.

28. Liu X, Shen J, Wang S, Yang X, Tong G, Zhang E. A 16000-year pollen record of Qinghai Lake and its paleo-climate and paleoenvironment. Chin Sci Bull. 2002;47(22):1931-6. https://doi.org/10.1360/02tb9421.

29. Long H, Lai Z, Wang N, Li Y. Holocene climate variations from Zhuyeze terminal lake records in east Asian monsoon margin in arid northern China. Quaternary Sci. 2010;74:46-56. https://doi.org/10.1016/j.yqres.2010.03. 009.

30. Long $H$, Lai Z, Wang N, Zhang J. A combined luminescence and radiocarbon dating study of Holocene lacustrine sediments from arid northern China. Quat Geochronol. 2011;6(1):1-9. https://doi.org/10.1016/j.quageo. 2010.06.001.

31. Luo C, Peng Z, Yang D, Liu W, He J, Liu G, Zhang P. Paleoclimate of Lop Nur and the response to global change by geochemical elements multianalysis. Geochimica. 2008;37:139-48. https://doi.org/10.7666/d.y1412 618.

32. Meybeck M. Global analysis of river systems: from Earth system controls to anthropocene syndromes. Phil Trans R Soc Lond B. 2003;358:1935-55 https://doi.org/10.1098/rstb.2003.1379.

33. Meyers PA. Organic geochemical proxies of paleoceanographic, paleolimnologic and paleoclimatic processe. Org Geochem. 1997;27:213-50. https://doi.org/10.1016/S0146-6380(97)00049-1.

34. Meyers, P.A., Ishiwatari, R., 2008. Organic Matter Accumulation Records in Lake Sediments Physics and Chemistry of Lakes. In Lerman A, Imboden D, Gat J Eds. Physics and Chemistry of Lakes Second Edition, Springer Verlag, Berlin, pp. 279-328. https://doi.org/10.1007/978-3-642-85132-2_10.

35. Meyers PA, Vergés EL. Lacustrine sedimentary organic matter records of Late Quaternary paleoclimates. J Paleolimnol. 1999;21:345-72. https://doi. org/10.1023/a:1008073732192.

36. Morrill C, Overpeck JT, Cole JE, Liu KB, Shen C, Tang L. Holocene variations in the Asian monsoon inferred from the geochemistry of lake sediments in central Tibet. Quaternary Res. 2006;65:232-43. https://doi.org/10. 1023/a:1008073732192.

37. Mumma, S.A., Whitlock, C., Pierce, K., 2012. A 28,000 year history of vegetation and climate from lower Red Rock Lake, centennial Valley, southwestern Montana, USA. Palaeogeogr Palaeoecol. 326-328, 30-41. https://doi.org/10.1016/j.palaeo.2012.01.036

38. Müller BM, Maerki M, Schmid M, Vologina EG, Wehrli B, Wüest A, Sturm M. Internal carbon and nutrient cycling in Lake Baikal: sedimentation, upwelling, and early Diagenesis. Global Planet Change. 2005;46:101-24. https://doi.org/10.1016/j.gloplacha.2004.11.008.

39. O'Leary MH. Carbon isotopes in photosynthesis. Bioscience. 1988;38:32836. https://doi.org/10.2307/1310735.

40. Piao $S$, Ciais $P$, Friedlingstein $P$, Peylin $P$, Reichstein $M$, Luyssaert $S$, Margolis H, Fang J, Barr A, Chen A, Grelle A, Hollinger D, Laurila T, Lindroth A, Richardson A, Vesala T. Net carbon dioxide losses of northern ecosystems in response to autumn warming. Nature. 2008;451:49-52. https://doi.org/ 10.1038/nature06444

41. Prentice IC, Harrison SP, Bartlein PJ. Global vegetation and terrestrial carbon cycle changes after the last ice age. New Phytol. 2011;189(4):988-98. https://doi.org/10.1111/j.1469-8137.2010.03620.x.

42. Quade J, Dente E, Armon M, Dor YB, Morin E, Adam O, Enzel Y. Megalakes in the Sahara? A review. Quat Res. 2018;90(2):253-75. https://doi.org/10. 1017/qua.2018.46

43. Ramsey BC. Radiocarbon calibration and analysis of stratigraphy: the oxcal program. Radiocarbon. 1995;37:425-30. https://doi.org/10.1017/ s0033822200030903.
44. Reheis MC, Adams KD Oviatt CG, Bacon SN. Pluvial lakes in the Great Basin of the western United States-a view from the outcrop. Quatern Sci Rev. 2014;97:33-57. https://doi.org/10.1016/j.quascirev.2014.04.012.

45. Running S, Mu Q, Zhao M. MOD17A3HGF MODIS/Terra Net Primary Production Yearly Gap-Filled L4 Global 500m SIN Grid V006. 2019. NASA EOSDIS Land Processes DAAC. https://doi.org/10.5067/MODIS/MOD7A 3HGF.006.

46. Shen J. Spatiotemporal variations of Chinese lakes and their driving mechanisms since the last glacial maximum: a review and synthesis of lacustrine sediment archives. Sci Bull. 2013;58:17-31. https://doi.org/10. 1007/s11434-012-5510-7.

47. Shen J, Liu XQ, Ryo M, Wang SM, Yang XD. A high-resolution climatic change since the Late Glacial Age inferred from multi-proxy of sediments in Qinghai Lake. Sci China Earth Sci. 2004;34:582-9. https://doi.org/10. 1360/03yd0148.

48. Stuiver, M., Reimer, P.J., Reimer, R.W., 2019. CALIB 7.1. http://calib.org, accessed 2019-11-11.

49. Tarnocai C, Canadell JG, Schuur EA, Kuhry P, Mazhitova G, Zimov S. Soil organic carbon pools in the northern circumpolar permafrost region. Global Biogeochem Cycles. 2009;23:2. https://doi.org/10.1029/2008G B003327.

50. Treat $C$, Kleinen T, Broothaerts N, Dalton A, Dommain R, Douglas T, Drexler J, Finkelstein S, Grosse G, Hope G, Hutchings J, Jones M, Kuhry P, Lacourse T, Lähteenoja O, Loisel J, Notebaert B, Payne R, Peteet D, Sannel A, Stelling J, Strauss J, Swindles G, Talbot J, Tarnocai C, Verstraeten G, Williams C, Xia Z, Yu Z, Väliranta M, Hättestrand M, Alexanderson H, Brovkin V. Widespread global peatland establishment and persistence over the last 130,000 y. PNAS. 2019;116:4822-7. https://doi.org/10.1073/pnas.18133 05116

51. Wada Y, Beek L, Viviroli D, Dürr H, Weingartner R, Bierkens M. Global monthly water stress: 2 . Water demand and severity of water stress. Water Resour Res. 2011;47:W07518. https://doi.org/10.1029/2010WR009792.

52. Wagner $B$, Melles $M$, Jürgen $H$, Niessen F, Hubberten HW. Holocene climate history of geographical society $\varnothing$, east greenland-evidence from lake sediments. Palaeogeogr Palaeoecol. 2000;160:45-68. https://doi.org/ 10.1016/S0031-0182(00)00046-8.

53. Wang J, Song C, Reager J, Yao F, Famiglietti J. Recent global decline in endorheic basin water storages. Nat Geosci. 2018;11:926-32. https://doi. org/10.1038/s41561-018-0265-7.

54. Wang M, Chen H, Yu Z, Wu J, Zhu Q, Peng C, Wang Y, Qin B. Carbon accumulation and sequestration of lakes in china during the Holocene. Global Change Biol. 2015:21:4436-48. https://doi.org/10.1360/03yd0148.

55. Wang RL, Scarpitta S, C., Zhang, S., C., Zheng, M.P., . Later Pleistocene/ Holocene climate conditions of Qinghai-Xizhang plateau Tibet. based on carbon and oxygen stable isotopes of Zabuye lake sediments. Earth Planet Sci Lett. 2002;203:461-77. https://doi.org/10.1016/s0012-821x(02) 00829-4.

56. Wieder, W.R., Boehnert, J., Bonan, G.B., Langseth, M., 2014. Regridded Harmonized World Soil Database v1.2. Data set. [http://daac.ornl.gov] from Oak Ridge National Laboratory Distributed Active Archive Center, Oak Ridge, Tennessee, USA. http://dx.doi.org/10.3334/ORNLDAAC/1247.

57. Yoshi MS, Daiana A, Mark R, Jonas G, Carolina L, Robert L, Edemar A, Dunia U, Denise S, José I. The legacy of 4,500 years of polyculture agroforestry in the eastern amazon. Nat Plants. 2018;4:540-7. https://doi.org/10.1038/ s41477-018-0205-y.

58. Williamson CE, Saros JE, Vincent WF, Smol JP. Lakes and reservoirs as sentinels, integrators, and regulators of climate change. Limnol Oceanogr. 2009;54:2273. https://doi.org/10.4319/lo.2009.54.6_part_2.2273.

59. Zhang CJ, Chen FH, Shang HM, Cao J. The paleoenvironmental significance of organic carbon isotope in lacustrine sediments in the arid China: an example from Sanjiaocheng palaeolake in Minqin. Quat Sci. 2004;24:88-94. https://doi.org/10.3321/j.issn:1001-7410.2004.01.011.

60. Zhao LY, Lu H, Zhang E, Wang X, Ge S, Chen Y, Zhang H, Wu B. Lake-level and paleoenvironment variations in Yitang lake, northwestern China during the past $23 \mathrm{ka}$ revealed by stable carbon isotopic composition of organic matter of lacustrine sediments. Quat Sci. 2015;35:172-9. https:// doi.org/10.11928/j.issn.1001-7410.2015.01.16. 
Publisher's Note

Springer Nature remains neutral with regard to jurisdictional claims in published maps and institutional affiliations.
Ready to submit your research? Choose BMC and benefit from:

- fast, convenient online submission

- thorough peer review by experienced researchers in your field

- rapid publication on acceptance

- support for research data, including large and complex data types

- gold Open Access which fosters wider collaboration and increased citations

- maximum visibility for your research: over 100M website views per year

At BMC, research is always in progress.

Learn more biomedcentral.com/submissions 